\title{
Notes on African plants
}

\author{
VARIOUS AUTHORS
}

IRIDACEAE

\section{TAXONOMIC NOTES ON ARISTEA (ARISTEOIDEAE) IN TROPICAL AND EASTERN SOUTHERN AFRICA}

The Afro-Madagascan Aristea Ait., only genus of Iridaceae subfam. Aristeoideae Goldblatt, comprises some 58 species of rhizomatous, evergreen perennials. The genus is currently subdivided into three subgenera: two of them, subg. Aristea (18 spp.) and subg. Pseudaristea (Pax) Goldblatt (9 spp.) are restricted to the southern African winter-rainfall zone in the southwest of the subcontinent (Goldblatt 2012), whereas subg. Eucapsulares (Goldblatt) Goldblatt (31 spp.) occurs widely across sub-Saharan Africa, where we now recognize 24 species. There are also eight species in Madagascar, one of them, A. goetzei Harms, shared with highlands of southern Tanzania (Goldblatt et al. 2013). Five species are shared between tropical and southern Africa, five are exclusively tropical African, and 13 species are restricted to southern Africa, three of them restricted to the southern African winter rainfall zone (Table 1).

The systematics of Aristea is relatively well understood in tropical Africa as a result of accounts of the genus for Flora Zambesiaca (Goldblatt 1993), Flora of East Tropical Africa (Goldblatt 1996a), Flora of Ethiopia (Goldblatt 1997) and Flore d'Afrique Centrale (Geerinck 2005). Nevertheless, some taxa require comment and clarification. Aristea djalonis Hutch., from the West African highlands, has been confused with $A$. angolensis Baker (e.g. Hepper 1968), but we consider it quite distinct from that species and most likely more closely related to the eastern and southern African $A$. torulosa Klatt (better known by its later synonym $A$. woodii N.E.Br.).

The taxonomy of a second species, $A$. abyssinica Pax, requires modification: $A$. bequaertii De Wild. was treated as a subspecies of $A$. alata Baker by Weimarck (1940) in a revision of the genus, but Geerinck (2005) included it without comment in $A$. abyssinica. We agree that $A$. bequaertii is more closely related to $A$. abyssiniica than to the East African A. alata, but some features of the taxon suggest it is better treated as a separate species. The types of $A$. bequaertii and of $A$. homblei De Wild. share with $A$. abyssinca and $A$. alata a stem consisting of a long basal internode, but whereas the latter two species have a single subterminal leaf subtending the single or pair of inflorescences (always binate rhipidia in the genus but called flower clusters here), $A$. bequaertii consistently has two cauline leaves, one inserted a short distance below the upper. This feature is not seen in $A$. abyssinica and in conjunction with some unusual floral features indicates to us that these plants represent a separate species.

Lastly, Aristea gerrardii Weim. (Weimarck 1940), recognized by Goldblatt (1993) in his account of the genus in Flora Zambesiaca, is, we now conclude, a later name for A. compressa Baker (1877), and we accordingly reduce it to synonymy under that species. The two taxa share a multi-branched compound inflores-

TABLE 1.-Distribution of species of Aristea occurring in tropical Africa with ranges by country

\begin{tabular}{|c|c|c|}
\hline Aristea species & Countries in tropical Africa & Countries outside tropical Africa \\
\hline abyssinica Pax & $\begin{array}{l}\text { Burundi, Cameroon, Congo, Ethiopia, Kenya, Malawi, } \\
\text { Nigeria, Rwanda, Tanzania, Uganda, Zambia, Zimbabwe }\end{array}$ & Lesotho, South Africa, Swaziland \\
\hline alata Baker & Ethiopia, Kenya, Tanzania, Uganda & \\
\hline angolensis Baker & $\begin{array}{l}\text { Angola, Burundi, Congo, Ethiopia, Kenya, Malawi, Nigeria, } \\
\text { Tanzania, Uganda, Zambia, Zimbabwe }\end{array}$ & Lesotho, South Africa, Swaziland \\
\hline bequaertii De Wild. & Congo (only southern Shaba) & \\
\hline compressa Buching. ex Baker & Mozambique & South Africa, Swaziland \\
\hline djalonis A.Chev. ex Hutch. & Guinea, Nigeria, Sierra Leone & \\
\hline ecklonii Baker & $\begin{array}{l}\text { Burundi, Cameroon, Congo, Malawi, Mozambique, Rwanda, } \\
\text { Tanzania, Uganda, Zambia, Zimbabwe }\end{array}$ & South Africa, Swaziland \\
\hline goetzei Harms & Tanzania & Madagascar \\
\hline nyikensis & Congo, Malawi, Tanzania, Zambia & \\
\hline polycephala Harms & Malawi, Mozambique, Tanzania & \\
\hline torulosa Klatt & Angola, Malawi, Mozambique, Tanzania, Zambia, Zimbabwe & Lesotho, South Africa, Swaziland \\
\hline
\end{tabular}


cence and compressed, 2-winged stems, and cited differences between them, especially in spathe and bract size, seem to us negligible once features of a third species, A. parviflora Baker, which was mistakenly included in A. compressa by Weimarck (1940) and Vincent (1985), are removed from consideration. After examining the type and other material of $A$. parviflora, a montane, local endemic of Eastern Cape, we conclude it is correctly a separate species and we provide a description of the species below, raising it from synonymy in $A$. compressa.

1. Aristea djalonis: the West African Aristea djalonis, named for the Fouta Djalon highlands in Guinea and southern Senegal, was first collected by Auguste Chevalier, the French botanist and plant explorer. Chevalier gave his collection the manuscript name Anthericum djalonis and published just the name in 1920 in a list of his plant collections (Chevalier 1920). The species was treated as Aristea djalonis in a brief (and taxonomically invalid) entry in Flora of West Tropical Africa (Hutchinson \& Dalziel 1936), where it was diagnosed in the key with Hutchinson listed as author. A valid, extended description was provided later (Hutchinson 1939). Superficially, collections of the species from Guinea, Nigeria and Sierra Leone resemble the widespread $A$. angolensis, and $A$. djalonis was included in that species by Weimarck (1940) and subsequently by Hepper (1968) in the second edition of Flora of West Tropical Africa.

One of four species of the genus that occur in West Africa (Table 1), Aristea djalonis can readily be distinguished by the flowering stem, which is simple or few-branched and compressed, conspicuously so below the middle of the inflorescence and about $4 \mathrm{~mm}$ wide, and sharply angular to narrowly winged. In A. angolensis, the stem is slender and oval to terete in section. The inflorescence spathes and bracts also differ, those of A. djalonis being oblong, 9-11 mm long, and dark green or brown in the centre, becoming membranous toward the edges and light, translucent brown. Bracts of A. angolensis are slightly shorter, dark green to blackish (black when dry) in the center and translucent white on the edges. The bracts of $A$. djalonis recall those of the south tropical and eastern southern African $A$. toru$l o s a$, and it is to this species that $A$. djalonis is probably most closely related. A species of Aristea endemic to West Africa is surprising, but there are at least five other endemic Iridaceae there, including two species of Zygotritonia and three of Gladiolus (Goldblatt 1989, 1996b).

Aristea djalonis A.Chev. ex Hutch. in Bulletin of Miscellaneous Information, Royal Botanical Gardens, Kew 1939: 246 (1939). [Hutch. in Hutch. \& Dalziel, Flora of West Tropical Africa 2: 376 (1936) nom. inval. Anthericum djalonis A.Chev.: 648 (1920), nom. nud.]. Type: Guinea, Fouta Djalon, Plateau de Dalaba, 'Anthericum djalonis,' Sept.-Oct. 1907 (fr.), Chevalier 18859 (P, holo.!).

Plants 400-600 $\mathrm{mm}$ high. Stem compressed and 2-angled to narrowly winged, $\pm 4 \mathrm{~mm}$ wide in middle, $\pm 3 \mathrm{~mm}$ wide below first flower cluster, often simple or 1-3-branched. Leaves 4-6, narrowly sword-shaped, mostly 6-10 mm wide, firm, basal and cauline, decreasing in size above. Flower clusters several per axis in lax spicate arrangement, sessile except terminal; terminal mostly 4-flowered, laterals mostly 2-flowered; spathes and bracts $8-10 \mathrm{~mm}$ long, dark brown in center, membranous and translucent brown toward edges, becoming torn and fringed with age. Flowers pale blue (or white), tepals $\pm 12 \mathrm{~mm}$ long. Filaments $\pm 6 \mathrm{~mm}$ long; anthers \pm $2 \mathrm{~mm}$ long. Ovary subglobose, $\pm 3 \mathrm{~mm}$ long; style \pm 6 $\mathrm{mm}$ long, 3-lobed at apex, lobes fringed. Capsules sessile, ovoid, 8-11 mm long. Seeds unknown. Flowering time: December and January.

Distribution: Guinea, Sierra Leone, Nigeria, in highland grassland.

Diagnosis and relationships: Aristea djalonis is distinguished from the other tropical African species of the genus by the compressed stem, about $4 \mathrm{~mm}$ wide in the middle, slightly angled to narrowly winged, bearing sessile lateral flower-clusters on the main axis, which is usually unbranched and the short, partly transparent, entire or lightly torn spathes, 9-11 mm long. When the stem is branched, the one to three branches are comparatively short and unusually slender. The several leaves are mostly 6-10 mm wide, whereas leaves of A. angolensis are usually narrower, often less than $5 \mathrm{~mm}$ wide.

\section{Representative specimens}

GUINEA.-Fouta Djalon, Diaguissa, 1 300-1 400 m, 18 Apr. 1905 (fr.), Chevalier 12652 (P); environs of Kindia, Benna, $1000 \mathrm{~m}$, June 1937, Jacques-Felix 1756 (P); Mt Loma, env. de Mali, Oct. 1937 (fr.), Jacques-Felix 1973 (P); Dalaba, roadside near Forestry House, 23 June 1962, Adames $277(\mathrm{~K})$.

SIERRA LEONE.-Lome Mtns, 16 Aug. 1945, Jaeger 985 (K MO). Loma Mtns, grassland at $5000 \mathrm{ft}, 17$ June 1966, Morton 3587 (K); Loma Mtns, Bintumane Peak, 6000 ft, 2 May, 1949, Deighton 5099 (K); Loma Mtns, Bintumane, grassland at summit of peak, 14 Aug. 1945 (fr.), Jaeger 985 (MO); Kabala, Loma Mtns, 8 Aug. 1964 (fr.), Adam 26716 (MO).

NIGERIA.--Northern: between Bukuru and Hepham, $4300 \mathrm{ft}$ [1 310 m], 4 July 1921, Lely 342 (K).

2. Aristea bequaertii: first collected in 1912, Aristea bequaertii remains a puzzling plant. Restricted to southern Shaba Province of the Democratic Republic of Congo (DRC), it is obviously closely allied to A. abyssinica and $A$. alata, with which it shares a flowering stem consisting of a long, basal internode, but unlike these species it bears two (sometimes three) cauline leaves, the uppermost of these not inserted at the base of the terminal flower cluster. Plants bear a terminal flower cluster distant for the uppermost cauline leaf and sometimes one in each cauline leaf axil, the lower of these more often stalked and the upper sessile. The pale blue to almost white flowers have blue anthers and pollen (verified from photos provided by M. Séleck), unique in subg. Eucapsulares, in which yellow anthers and pollen are the rule. Also unusual are the erect stamens surrounding the style. In other species of the subgenus, the stamens diverge and the style is eccentric.

Elsewhere in Shaba and further north in the highlands of eastern DRC, and in Burundi, Rwanda and adjacent Zambia, typical $A$. abyssinica seems to be common and can easily be distinguished from $A$. bequaertii. The species was treated by Weimarck (1940) as A. alata subsp. bequaertii, with $A$. abyssinica as a second subspecies of $A$. alata. As currently circumscribed, $A$. alata is restricted to Kenya, Uganda and Ethiopia and is as tall 
as some collections of $A$. bequaertii but it has a single (rarely two) cauline leaves, always close to the stem apex, the uppermost subtending the terminal flower cluster. The broader leaves and prominently stalked capsules on pedicels up to $25 \mathrm{~mm}$ render $A$. alata unmistakable. Geerinck (2005), in Flore d'Afrique Centrale included $A$. bequartii in $A$. abyssinica without comment. Additional collections of $A$. bequaertii with well preserved flowers and with ripe capsules are needed to amplify our knowledge of the species.

We provisionally include Aristea homblei, described by De Wildeman (1913) at the same time as A. bequaertii, in synonymy as did Weimarck, but note that the type consists of rather different plants. Much shorter, the specimens range in height from as little as $80 \mathrm{~mm}$ to 120 $\mathrm{mm}$, bear two cauline leaves and the flattened stems are somewhat contracted. In some plants of the collection, the terminal flower cluster is sessile, but in others they are stalked and distant from the uppermost cauline leaf. More collections of Aristea in Shaba are needed to better understand the variation in $A$. bequaertii and its possible synonym, A. homblei.

Aristea bequaertii $D e$ Wild. in Repertorium specierum novarum regni vegetabilis 11: 509 (1913). $A$. alata Baker subsp. bequaertii (De Wild.) Weim.: 46 (1940). Type: Congo, [Shaba], Lubumbashi [Elisabethville], 3 Apr. 1912, Bequaert 303 [BR, lecto.!, designated by Weimarck: 36 (1940)].

Aristea homblei De Wild.: 509 (1913). Type: Congo, [Shaba], Welgelegen, 1912, Corbusier sub Homblé 615 (BR, syn.! [3 sheets]).

Plants (80-)180-400 mm high. Stem compressed, 2-winged, 2-4 mm wide, consisting of 1 long basal internode and 2 or 3 shorter internodes in upper $1 / 3$, bearing 2 or 3 short leaves, these often subtending a sessile or stalked flower cluster. Leaves several, \pm linear, lower 3 or 4 basal, reaching to \pm middle of stem, $2.0-3.5 \mathrm{~mm}$ wide, cauline leaves 2 or 3 , progressively shorter above. Flower clusters 1-2(-4), lateral clusters if present sessile or on short branches, the terminal remote from uppermost leaf, each 2-4-flowered; spathes 7-10 $\mathrm{mm}$ long, green with broad membranous margins, keel sharply angled and hyaline, bracts membranous, becoming \pm dry, translucent light brown, slightly shorter than spathes. Flowers blue to white, \pm sessile, tepals subequal, spreading, ovate, 9-12 $\mathrm{mm}$ long. Stamens erect and remaining contiguous, enclosing style; filaments 4-5 $\mathrm{mm}$ long, purple; anthers $1.2-1.5 \mathrm{~mm}$ long, pale to deep blue. Ovary \pm ellipsoid, $\pm 5 \mathrm{~mm}$ long before pollination, rapidly enlarging later; style slightly exceeding anthers, blue-purple, terminating in 3-stalked stigmatic lobes. Capsules ovoid-ellipsoid, 7-8 mm long. Seeds unknown. Flowering time: mostly December and January.

Distribution: Congo, Shaba, restricted to southern Shaba, mostly (always?) in copper enriched soils, in grassland, woodland and marshy sites. With just a handful of collections and from a small portion of Shaba, the conservation status of Aristea bequaertii should perhaps be regarded as RARE and possibly EN, Endangered, given its occurrence in copper-rich soils and close to areas under intensive mining activity.

\section{Representative specimens}

CONGO.-Shaba. Kitimbi, in swamp, Jan. 1908, Kassner 2326 (B, K); 14 km N of Mitwaba, 16 Jan 1960, Duvigneaud 5075 (BRLU); Welgelegen, Corbisier 615b (BR); Keyberg, open forest, 9 Jan. 1957, Detilleux 370 (BR); collines de cuivre [copper hills] de Tenke, Kachimilumbe (2), 10 Jan. 2012, Séleck, Delhaye \& Ilunga 210 (BR), Kachimilumbe (3), 11 Jan. 2012, Séleck, Delhaye \& Ilunga 210 (BR).

3. Aristea compressa: both A. compressa Baker (1877) and the newly described $A$. gerrardii Weimarck were recognized by Weimarck (1940) in his account of the genus and both were also recognized by Vincent (1985) in his treatment of Aristea for eastern southern Africa. Goldblatt (1993) accordingly recognized A. gerrardii in coastal Mozambique in Flora Zambesiaca. Weimarck, and later Vincent, distinguished the two species by their inflorescence spathes, on the spurious grounds that those of $A$. compressa were significantly smaller. They are in fact virtually the same size in the type material of both species. Part of the problem was that several specimens included in $A$. compressa by both authors are a second species, A. parviflora Baker (1906), which has a comparably branched flowering stem to that of $A$. compressa but shorter inflorescence spathes, significantly smaller flowers and does not have a flattened flowering stem. Restricted to northeastern Eastern Cape, A. parviflora is a montane species, evidently allied to $A$. angolensis.

The types of Aristea compressa and A. gerrardii, both of which are from coastal KwaZulu-Natal, South Africa, share a compressed flowering stem, sharply 2-angled or narrowly 2-winged, flower clusters arranged in a compound pseudopanicle with the central axis dominant, and lanceolate spathes and floral bracts $\pm 5-8 \mathrm{~mm}$ long, green or brown in the midline, transparent and becoming torn along the edges. The small, blue flowers differ hardly at all from those of other tropical African and several eastern southern African species. We provide revised descriptions of $A$. compressa and $A$. parviflora below with adjusted nomenclature of $A$. compressa.

Aristea compressa Buching. ex Baker in Journal of the Linnean Society, Botany 16: 111 (1877) [A. compressa Buching. in Krauss, Flora 28: 309 (1845), nom. nud.]. Type: South Africa, [KwaZulu-Natal], forest margins near Umlaas River, 1840, Krauss 358 (K, holo.!, MO [2 sheets], iso.!).

Aristea gerrardii Weim.: 17 (1940), syn. nov. Type: South Africa, [KwaZulu-Natal], without precise locality or date, Gerrard 393 (K, holo.!; P, iso.!).

Plants 300-750 mm long. Stem flattened almost to apex, narrowly winged, several- to many branched (one order), but never dichotomously. Leaves narrowly sword-shaped to linear, leathery, sometimes weakly pleated, mostly $8-12 \mathrm{~mm}$ wide, $\pm 1 / 2$ as long as stem. Flower clusters many in compound pseudopaniculate arrangement, lateral clusters sessile, each 2-4-flowered; spathes and bracts lanceolate, mostly 5-8 $\mathrm{mm}$ long, green or brown in midline, transparent along margins and upper half, becoming torn. Flowers blue, outer tepals 10-11 ×6-7 mm, inner $\pm 9 \times 4 \mathrm{~mm}$. Stamens: filaments $\pm 4 \mathrm{~mm}$ long, anthers $1.7-2.0 \mathrm{~mm}$ long. Ovary broadly conical, $\pm 2 \mathrm{~mm}$ long, on short stalk \pm 1 $\mathrm{mm}$ long; style $\pm 5 \mathrm{~mm}$ long, broadly 3-lobed, reaching 
mid-anther level. Capsules ovoid, $\pm 5 \mathrm{~mm}$ long, \pm sessile. Seeds angular-prismatic, reticulate. Flowering time: August to January.

Distribution: Aristea compressa extends from Pebane in coastal northern Mozambique through KwaZuluNatal to Port St Johns in Eastern Cape, South Africa, occurring mainly in coastal sites, often in marshy habitats, but locally inland, as at Drummond (KwaZuluNatal) and Mbabane (Swaziland), then often in areas with sandstone or quartzite substrates (Figure 1). The species is naturalized in Hawai' $i$.

\section{Representative specimens}

MOZAMBIQUE.-Maputo: Matutuíne, between Zitundo and Manhoca, 29 Nov. 1979, De Koning 7706 (BR, MO, NBG). Pebane: Pebane, Aug. 1950, Munch 261 (SRGH).

SWAZILAND._-2631 (Mbabane): Mbabane, (-AC), 14 Jan. 1951, Compton 22366 (NBG), 'near houses, ?garden escape', 27221 (NBG, PRE); Mbabane, Poliniane River, (-AC), 6 Nov. 1956, Compton 26198 (PRE).

EASTERN CAPE.-3129 (Port St Johns): Mkambati Nature Reserve, hills N of airstrip, (-BD), 9 Dec. 1986, Nicholas \& Smook 2335 (MO, PRE); Port St. Johns, (-DA), 10 Dec. 1938, Prance s.n. (NBG), Nov. 1928, Dyer 1817 (GRA).

KWAZULU-NATAL.-2632 (Bella Vista): Kosi Bay, National Parks Board Camp, (-DD), Moll \& Strey 3819 (NH, PRE). 2831 (Nkandla): Hlabisa, Palm Ridge Farm, (-BB), Harrison $216(\mathrm{NH}$, PRE). 2832 (Mtubatuba): St. Lucia, eastern Shores State Forest, (BA), 13 Oct. 1983, Nicholas 1602 (MO). 2930 (Pietermaritzburg): Drummond, (-DA), 22 Oct. 1963, Bayliss 1729 (NBG); Clairmont, (-DD), Oct. 1896, Wood 6139 (PRE); Pinetown, (-DD), Hafstrom \& Acocks 267 (PRE), Oct. 1942, Fisher 351 (MO). 3030 (Port Shepstone): Isipingo Beach, (-BB), Ward 527 (NU); Port Shepstone, (-CB), Nov. 1905, Rogers 494 (GRA). 3130 (Port Edward): Port Edward, (-AA), Moss $19194(\mathrm{~J})$.

Aristea parviflora Baker in Bulletin of Miscellaneous Information, Royal Botanic Gardens, Kew: 25 (1906). Type: South Africa, [Eastern Cape], Insizwe Mtns, 28 Jan. 1895, Krook in Herb. Penther 556 (K, holo.!)

Plants 400-600 mm high. Stem slightly compressed, oval in section, with low raised angles decurrent on cauline leaves, repeatedly branched (one or two orders), main axis remaining dominant, branches ascending. Leaves \pm linear, leathery, basal $\pm 1 / 2$ as long as stem, mostly 4-6 mm wide, cauline leaves progressively shorter above. Flower clusters many in paniculate arrangement, sessile or stalked, each (1)2-4-flowered; spathes and bracts ovate to lanceolate, mostly 3.5-4.5 $\mathrm{mm}$ long, evidently translucent membranous with brown keels and shading brown near bases, becoming torn with age. Flowers blue, tepals $\pm 6 \mathrm{~mm}$ long, filaments \pm 2.5 $\mathrm{mm}$ long; anthers $\pm 1.5 \mathrm{~mm}$ long. Ovary globose-truncate, $\pm 2 \mathrm{~mm}$ diam., \pm sessile; style unknown. Capsules globose, $\pm 3.5 \mathrm{~mm}$ diam., sessile. Seeds unknown. Flowering time: January and February, probably also March. Figure 1.

Distribution: a narrow endemic, Aristea parviflora is known only from the Insizwe and Mt. Ayliff ranges of the southern Drakensberg of northeastern Eastern Cape. One of the collections was made along forest margins (Figure 1).

Diagnosis: described by J.G. Baker in 1906, the distinctive Aristea parviflora was included by both Wei-

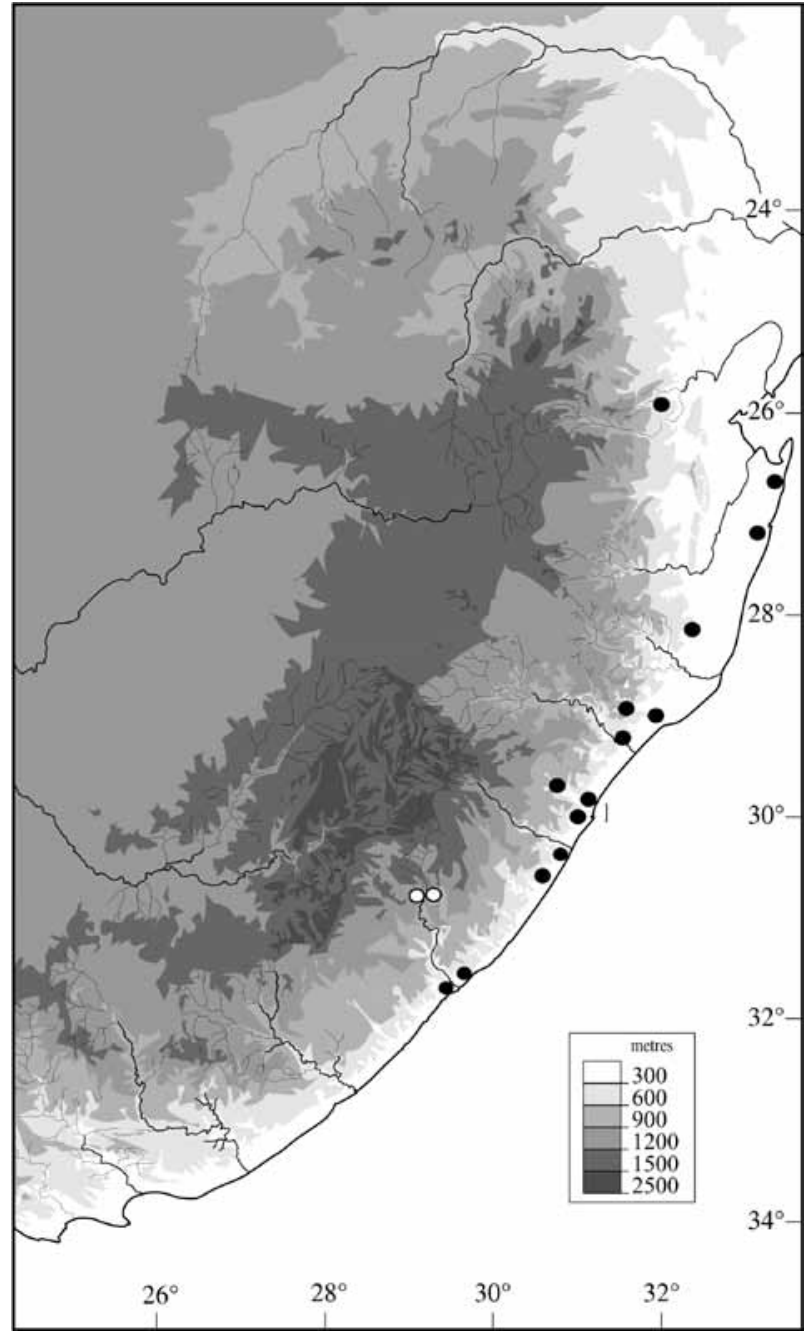

FIGURE 1.-Distribution of Aristea compressa $(\bullet)$ [excluding a record from Pebane, north of Beira in Mozambique] and $A$. parviflora (०).

marck (1940) and Vincent (1985) in A. compressa on spurious grounds. This narrow endemic has the smallest flowers in the genus, the tepals about $6 \mathrm{~mm}$ long and the flower thus about $12 \mathrm{~mm}$ in diameter, and correspondingly short filaments, about $2.5 \mathrm{~mm}$ long. Also distinctive are the globose capsules up to $3.5 \mathrm{~mm}$ in diameter and the stems are only slightly compressed with narrow raised angles; whereas the stems of $A$. compressa are flattened with the longer axis twice as long as the short axis and the stems are more-or-less winged. The tepals of $A$. compressa are 10-12 mm long, filaments 3.5-4.0 $\mathrm{mm}$ long and the capsules are ovoid and about $5 \mathrm{~mm}$ long

\section{Selected specimens}

EASTERN CAPE.-3029 (Kokstad): Griqualand East, near Clydesdale, \pm 915 m, (-BD), Feb. 1884, Tyson 2872 (BOL, K, PRE, SAM); forest margins near Mt Ayliff, (-BD), Feb. 1884, Tyson 1741 (BOL, SAM); Insizwa, Jan. 1895, Schlechter 6470 (BOL, GRA).

\section{ACKNOWLEDGEMENTS}

We thank Maxime Séleck for sharing his knowledge and collections of Aristea bequaertii and the curators of 
the following herbaria for loans and access to their collections: BOL, BR, K, NBG. We also thank Clare Archer for checking holdings at the Pretoria herbarium (PRE) for us.

\section{REFERENCES}

BAKER, J.G. 1877. Systema Iridearum. Journal of the Linnean Society Botany 16: 61-180.

BAKER, J.G. 1906. II.-Diagnoses Africanae, XVI. Bulletin of Miscellaneous Information [Royal Botanic Gardens, Kew] 1906 : 15-30.

CHEVALIER, A. 1920. Exploration botanique de l'Afrique occidentale française 1. Enumeration des plantes récoltées. 1. Paris, Lechevallier.

DE WILDEMAN, E. 1913. Decades novarum specierum florae katangensis. 1-VII. Repertorium specierum novarum regni vegetabilis 11: 501-524.

GEERINCK, D. 2005. Iridaceae. Flore d'Afrique Centrale. Jardin Botanique National de Belgique, Meise.

GOLDBLATT, P. 1989. Revision of the tropical African genus Zygotritonia (Iridaceae). Bulletin du Museum d'Histoire Naturelle, 4 sér. sect. B, Adansonia 11: 199-212.

GOLDBLATT, P. 1993. Iridaceae. Flora Zambesiaca 12, 4. Flora Zambesiaca Managing Committee, London.

GOLDBLATT, P. 1996a. Iridaceae. In R.M. Polhill (ed.), Flora of Tropical East Africa. A.A. Balkema, Rotterdam.

GOLDBLATT, P. 1996b. Gladiolus in Tropical Africa. Timber Press, Portland, OR.

GOLDBLATT, P. 1997. Iridaceae. In S. Edwards, S. Demissew \& I Hedberg (eds), Flora of Ethiopia 6: 162-183. University of Addis Ababa, Addis Ababa.

GOLDBLATT, P. 2012 [2013]. Aristea (Iridaceae: Aristeoideae), a subgeneric classification. Novon 22,4 (in press).
GOLDBLATT, P., PHILLIPSON, P.B. \& MANNING, J.C. 2013. The new species Aristea farafangana (Iridaceae) from Madagascar, biogeographic notes on Aristea in Madagascar and a revised key to the genus. Adansonia [doi: http://dx.doi.org/10.5252/ a2013n1a4], sér 3,3: 47-53.

HEPPER, N. 1968. Iridaceae. Pp. 138-142 in Flora of West Tropical Africa, ed. 2, 3(1). Crown Agents for Oversea Governments and Administrations, London.

HUTCHINSON, J. 1939. XXVIII-Tropical African plants: XVII. Bulletin of Miscellaneous Information, Royal Botanical Gardens, Kew. 1939: 241-247.

HUTCHINSON, J. \& DALZIEL, J.M. 1936. Iridaceae. P. 374-376 in Flora of West Tropical Africa 2,2. Crown Agents for the Colonies, London.

KRAUSS, F. 1845. Pflanzen des Cap- und Natal-Landes, gesammelt un zusammengestellt von Dr. Ferdinand Krauss. Flora 28: 305-315.

VINCENT, L.P.D. 1985. A partial revision of the genus Aristea (Iridaceae) in South Africa, Swaziland, Lesotho, Transkei and Ciskei. South African Journal of Botany 51: 209-252.

WEIMARCK, H. 1940. Monograph of the genus Aristea. Lunds Universitets Arsskrift N. F. Avd. 2, 36: 1-140.

\section{P. GOLDBLATT ${ }^{1,3}$, J.C. MANNING ${ }^{2,3}$}

${ }^{1}$ B.A. Krukoff Curator of African Botany, Missouri Botanical Garden, P. O. Box 299, St. Louis, Missouri 63166, USA. E-mail: peter.goldblatt@ mobot.org.

${ }^{2}$ Compton Herbarium, South African National Biodiversity Institute, Private Bag X7, 7735 Claremont, Cape Town. E-mail: j.manning@ sanbi.org.za.

${ }^{3}$ Research Centre for Plant Growth and Development, School of Life Sciences, University of KwaZulu-Natal, Pietermaritzburg, Private Bag X01, Scottsville 3209

MS. received: 2012-12-10 